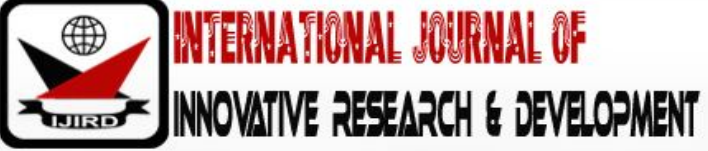

ISSN 2278 - 0211 (Online)

\section{Effects of Policy Networks on the Management of Common Pool Resources in Kenya: A Case of Mara North Conservancy, Narok County, Kenya}

\author{
Joseph Ole Saoli \\ Curator, Department of Public Policy and Administration \\ Kenvatta University, Kenya
}

\begin{abstract}
:
The main motivation of this research was to explore the effects of policy networks on the management of common pool resources with a bias on Mara North Conservancy in Narok County of the Republic of Kenya. It forms an important contribution to the debate on how policy networks influence the management of common pool resources, its use and promotion of good governance in the management of resources. The specific objectives of this study was to attempt to investigate the effects of Policy networks on the management of common pool resources in Kenya. To identify how governance structure within the policy networks influence the management of Mara North Conservancy, to investigate how governance processes within the policy networks affect management of Mara North Conservancy and lastly to assess how the use of information, technology and communication within policy networks affect the management of CPR. This study, therefore, seeks to fill the existing gap in the use of policy network approach in the management of CPRs particularly in Kenya. A framework is developed to analyze to what degree policy network approach affects management of CPRs. To achieve the objective of the research, open, closed questionnaires and interviews were used. The study, adopted a descriptive case study design in exploring the effects of policy networks and its effect on management of common pool resources, information technology and communication and the governance on the management of Mara North Conservancy. The target population for this study were the landowners of Mara North Conservancy, Board of governors, Employees, County officials and national government officials. According to a survey by the Kenya National Bureau of Statistics (2019), the total population in Mara north conservancy is 18,214. Target population for the study therefore was 21 members representing landowners, 560 employees, 8 Board of Governors of the Conservancy, 12 members of national government as well as 10 from the county government. The researcher obtained this Data from Kenya Wildlife Conservation Association website. The study interviewed Board of governors, national and county officers and others that have close interaction with the people in order to bring out policy implications of the management of common resources and administer questionnaires to other respondents in the study.
\end{abstract}

Keywords: Policy networks, Common pool resources, governance

\section{Introduction}

Policy network challenges are often in comparison to 'the tragedy of the commons' that is According to Hardin. The narrative has been further expounded in the 50 years since Hardin cited shared pastures as an example of the commons. Hardin pointed out that unregulated access to pastures would lead to over-exploitation through each individual's intention of maximizing his or her own gains by putting more livestock out to graze; Inconsequence, shared pastures would go into ruin. According to Hardin, any commons with a limited carrying capacity that is always open to all, in which those who pursue rational economic activities utilize them to maximize their own gains, inevitably becomes devastated. The individuals' freedom to pursue their own egocentric interests leads to the tragedy of the commons. To curb the situation, Hardin argued, 'mutual coercion mutually agreed upon' is needed in order to constrain each individual's freedom. Thus, the establishment of private property rights or the intervention and expansion of centralized state power over the commons has been proposed as a means to prevent the tragedy of the commons, Forsyth and Johnson (2014).

Elinor Ostromwork of, 'Governing the Commons' opened the likelihood of sustainable management of common pool resources (CPRs) through autonomous institutions from local people, rather than through privatization or state control. Elinor Ostrom and the extensive research by other scholars of common property emphasized the capacity of local communities as well as other social groups to manage common resources. They went ahead to provide insightful information for a shift towards co-management, and community based resource management. For good management of common resources, there is need to involve policy network and tap in their expertise, information, authority or funding (McGuire, 2002). These objectives are unlikely to be achieved if the resources possessed by other actors are not incorporated in the network (Klijn \& Koppenjan, 2012). It is from this backdrop Klijn (2010) argues that resources possessed by other organizations are crucial for the survival of another agency. On the other hand, Rhodes (2016) is in 
agreement that a network looks forward to exchange another network's resources to be in a position to achieve its objectives. It is believed that when numerous participants come together in the form of networks, there is exclusive exchange of potential solutions, agency policies and programs and technologies (Agranoff, 2007). Similar sentiments are shared by Howlett (2000) that government aims and initiatives are to be successful if at all various actors are interacted to ensure general support.

Participant broadening not only educates and informs, but this kind of inclusivity helps to make adjustments to lost interagency potential, acquire potential resources and help to eliminate support and information gaps Agranoff (2014). The argument above is in line with Koppenjan \& Klijn (2012) that greater dependencies have thrived among networks as a result of an increase in specialization and dynamics in knowledge and product enhancement. Strategies from different players determine a given policy or outcome and demonstrates why dependence among actors is crucial. Firms are not solely responsible in solving some issues but needs input from other networks. Klijn and Koppenjan (2012) perspective is that there is no single actor in the world who has amble steering prowess to determine strategic actions of the other actors. Therefore, the links between networks serve as communication channels and particularly for the exchange of expertise, policy resources, information and trust (Rhodes, 2016).

According to Klijn (2010), Policy networks are worth paying into account. Forsyth et.al (2014) is of the same perspective that successful program implementation, requires recognition that networks are important. In the European community, the policy network structure has really helped in identifying the role of network interdependencies and chains that allowed environmental non-governmental organisations to play a pivotal role in Regional Fund reforms. On the other hand, in Korea and Taiwan, personal and institutional networking was identified to be a powerful tool for expatriating experts who preferred working overseas (Song, 2003). Song further noticed that a well-designed and properly maintained network provides a forum and helps to foster a sense of belonging among innovators hence reinforcing their loyalty to their homeland.

Network actors have mutual interest in some policy areas which get linked by both direct and indirect contacts to form a good environment by which policy ideas emerge, attract attention and which loose national organizations coordinate a wide range of efforts to influence policy Fowler (2000). Policy network study recognizes that there might exist different levels of political support to different policy issues; this basically demonstrates why some issues receive more attention while others receive less attention. The attention issues receive, depends on the policy network's beliefs, motivations, judgments on feasibility and perception of the political setup which goes a long way in explaining the public policies and how it takes shape, Sidney (2017).

One example of such a value conflict over complex issues within the framework of policy network approach is the management and conservation of Mara North Conservancy in Kenya (MNC). The MNC is considered the most important of the twelve main wildlife conservancies in Mara ecosystem because of its economic, social and environmental contribution to the country. The importance of the MNC is related to the economic and ecosystem services it provides, such as economic empowerment, controlled grazing and reduced overgrazing, soil erosion control and protection of biodiversity which provides favourable conditions for tourism to thrive in Kenya. Nevertheless, these benefits have continued to fade away despite the involvement of both Narok County Government and the Government of Kenya astounding efforts to put policies to protect the country's most valuable asset. In spite of its national importance, large parcels of land of the Mara North conservancy has been taken over by the managing company with little benefit to the landowners and with more human-wildlife conflict escalating. Much of this damage has taken place in the past few years. Perpetration of economic sabotage and continuous economic growth of inequality has led to death, maiming and destruction of property in the Mara North Conservancy. 10 people for the last year have been injured, averagely 2 people killed and property worth $10,000,000$ lost as a result of conflicts (KWCA,2019).

Statistics indicates that 60 percent of the conservancy land cover has been taken over for ecotourism where more than 800 landowners have leased their land to controlled grazing reducing the number of livestock reared to merely 3,000 from 12,000 in 2009. 30 percent of total revenue collection from the conservancy ends up in the hands of 'unscrupulous' officials and few elites in the society. This trend has really raised a question on the role of policy networks in the management of resources.

\section{Literature Review}

\subsection{Policy Networks in the Management of Common Pool Resources}

Koppenjan and Klijn (2013) pointed out that policy network is a manifestation of concrete mixture of different logics. Policy networks that are properly managed serves as a platform through which the communication of innovations is actualized. Scholars from across disciplines have come into agreement that social and professional networks play a very crucial role in diffusing innovations and therefore, there is need for them to be given a proper attention. Creativity of involved individuals is the starting point of innovations that will help to solve the problem in place (Belussi and Stabber, 2012). Innovation offers an opportunity for development at personal level and at local level (Boren and Young, 2013). Creative thinking in the policy network has proved to pave way for expertise and skill crafting through individuals who possess experience and knowledge from a myriad of domains (Bilton, 2014). In other studies, by ((Garmestani 2013; Barnes et al. 2017; Bodin 2017) it was identified that changes to one part of a system may bring unforeseen and unpredictable changes across time and space to other parts of a linked system. This creates challenges for governance approaches which are not adaptive to changes in a system.

On the other hand, Johnson and Karlsson (2011) is of the opinion that innovation possess the ability of bringing together incompatible ideas and also help to combine them in a way that gives deep insights. Innovation is crucial to the 
understanding of a policy gap and in the development of artistic interventions and that organizations do not innovate or implement change, individuals do (Boren and Young, 2013). Street -level bureaucrats with their knowledge and power enables them to act autonomously and mould policy outcomes. Through their interactions with citizens, utilizing discretion, they have the capacity to shape public policy on the spot (Lipsky, 2010). Large and small, street-level bureaucrats may slowly mould their authority, routines, and culture relations around the emergence of a particular policy (Moynihan and Soss, 2014). According to Moynihan and Soss (2014) policy cannot always give authority to what matters to the outcomes at the local level since street-level bureaucrat's incentives and beliefs are central. They also emphasized these sentiments by suggesting that networks at different level management always use their ability to remake policy and help explain policy effects.

According to a study by Janssen (2013) the researcher highlighted that decision making is the most often encountered problem in everyday professional live. Decision making commonly represents the core process of solving complex and ill-structured problems. The researcher also pointed out that decision making is a vital component within complex problems such as diagnosis, design, negotiation, situation assessment, command and control even though some problems require only decision making. Ill-structured and complex problems entail iterative and sequential decisionmaking processes and that individuals possess different opinions and that they are required to reach a common decision. Coming closer home, a study conducted by Kariuki, Birner and Chomba (2018) clearly highlight an elaborate decisionmaking process that involved elections and nominations of community representatives for the Landowners Committee (LOC) and the Grazing Committee. However, there was no meaningful participation, which is an important element of management of CPRs. For instance, the members lamented about poor access to information from the Grazing Committee regarding designated grazing locations and general conservation management. After the project inception meeting in 2009 , there was an expectation that meetings would be held annually and it was most concerning that this expectation was not met; only one general meeting was held in 2014. It was also found that women never participated in decision making process of the management of the conservancy (Bedelian 2014).

According to Mechling (2010) providing individuals with information is a sign of constant communication therefore an influential strategy of capturing the mood of individuals in an organization. The above argument corresponds to Marcel, Ramasubbu, and Sambamurthy, (2011) that narrative information is of paramount importance when involves individual decision making. Consultative decision making facilitates the retrieval of relevant information from internal and external sources which is used to characterize decision making (Demir 2015). managers when faced with a looming crisis that needs a quick decision, they quickly retrieve relevant information from the gallery and request extra information from other network who have been in the similar scenario there before. These quick decisions are realized on the reduction of the effort spent on making decisions by examining less information, simplifying the weighing of cues, integration of less information, examining fewer cues and also significant effort reduction in retrieving cue values (Shah and Oppenheimer, 2008).

According Thomas Hobbes and Max Weber, power is conceived to be power over and that the likelihood that an actor in a social relationship is able to be in a state to carry out his or her own will irrespective of opposition. Max Weber also highlighted that application of physical force, threats and manipulation are modalities of power. Hannah Arendt explained that power is conceived when people engage in unrestricted communication channels or act in concert manner. According to Arendt's work, power is not something that can be owned by certain individuals and exercised over others but rather it exists between people. Brando et al (2019) indicated that power is relational as opposed to unilateral. He further indicated that threats, physical force and manipulation are the contrast of power. Arendt argued, that power cannot be kept or stored up in reserve for future eventualities, but exist only in actualization. Brando et. al. (2019) pointed out that this is possible if relations are established by not using violating words.

According to Elinor Ostrom (2012), she challenged the Hobbesian theory states that constitution of order is only possible if sovereigns are created to govern the subjects, monitor, and impose sanctions on all who would not comply. She pointed out that its possible for people to cooperate and have convincing commitments without there being an external enforcer. However, to achieve this, continuous and unconditional communication must take place. The same people should be able to choose freely an internal governing body and set rules which works well when the society is able to come up with common standards and agree on sanctioning mechanisms, in order to punish those that differ with the norms. It is equally important for the affected persons by the resource regime get to be involved in modification and making of rules, that's according to Ostrom (2012). Ostrom went ahead to highlight that power doesn't rest outside the institutions or in a centralised authority which is given the mandate to apply and enforce rules of action, but rather same power exists in between people in an agreement of cooperation between members themselves and is kept alive through constant communication and shared actions. Power that is exercised non-coercively and non-violently also compose a form of power in an organization. These is only possible where communication and participation help the networks to achieve the set goals (Reagan and Greve 2015).

Communication and participation play a role; this is by helping each other in the attainment of a set of goals. Networks which comprise a group of people who previously worked together require minimal attention to develop one intent and establish confidence and trust than will those groups who are new to each other. It is critical to inculcate trust in creating real power relationships. Therefore, it is because of trust that people agree to not only join hands but also work together. It has also been identified that genuine development of trust is as a result of experience and genuine familiarity between networks, Reagan and Greve (2015). Power and authority is very crucial to individuals as it will help them to participate in making of decisions as well as carrying them out. Reagan and Greve (2015) warned administrators that it isn't good to overlook power within their organizations, as well as in assessing the dimensions of their settings. Lipsky (2010) highlighted that public administrators also have power though it varies. Power therefore can be enhanced by 
through firm and strong, rightly organized localities, skilful leaders, organizational unity and spirit, expertise and specialized technical skills which is necessary for the quality delivery of services to the public. Lipsky went ahead to point out that 'street-level bureaucrats' who are government service providers have considerable autonomy. They are guided by civil service rules, measured by performance, as well as rules governing quality service delivery constraining top official's authority over others.

In a recent study by Kariuki (2018) perceptions regarding the power of actors to influence outcomes, it was identified that the group with the highest influence over the management of the conservancy is the Board and grazing committee. As a result of the immense power to influence distributive equity, payments and resource use regulations the Board and Committee were perceived as powerful. Surprisingly, according to the study, it was equally identified that even though tourists provided the ultimate source of the revenues, their influence over management of the conservancy was ranked among the lowest and this is mainly attributed to the engagement of benefit-sharing arrangement which does not depend directly on the number of tourists or the revenue created by tourism. The Tourism Partners were awarded slightly more influence than tourists, because they had an influence on the management of revenue distribution and on contract design (Kariuki et.al 2018). The informal institutional arrangements reflected in the power of the elites continue to exist preventing the achievement of procedural equity. A case in point is the absence of regular annual meetings and the fact that most land owners do not even have a copy of the contract.

\section{Methodology}

\subsection{Research Design}

The research adopted the descriptive case study research design. These study was used because it made it possible for the researcher to collect information through both personal accounts and observations made by the respondents concerning the topic of study. Furthermore, it gave them the freedom they needed to describe this topic from their own experiences rather than based on theory (Lambert, 2012). According to Mugenda and Mugenda (2003), a descriptive research design is a detailed and scientific process of answering research questions aimed at describing and gathering data about the current state of subjects or an event- under investigation. The authors articulate that, a descriptive research design employs descriptive statistics to describe and gather data about the subjects (Jackson, 2008). According to Mugenda and Mugenda (2003), this type of research design describes attitudes, values, characteristics, and possible behaviors of the subjects. Mugenda and Mugenda (2003) further argues that descriptive research design ensures that the researcher doesn't directly control independent variables as their manifestation has already occurred or because essentially cannot be manipulated. More importantly, the research employed the research design based on facts that, the study intended to examine an already existing aspect; the effects of policy networks on the management of Mara North Conservancy.

\subsection{Site of the Study}

Thestudy was carried out primarily in the Mara North Conservancy which is located in Narok County, in the semiarid rangelands of Southern Kenya. The conservancy is executed on a 74,000 acres' piece of land that is owned privately by 800 households from the Maasai community (Njogu and Dietz 2006; Mwangi' 2007a). The conservancy is bordering Maasai Mara Game Reserve and its vital for sustainability of the famous Serengeti wildebeest migrations as well as the African wild dog and black rhino that is highly threatened. Since the area is vast and the research cannot be undertaken in every corner of the County, the researcher purposely selected Mara North Conservancy as the main area of study. The area was selected due to the challenges in terms of governance, persisting conflicts as a result of inequality in distribution of resources, grazing land and leadership that have been observed in the area.

\subsection{Data Collection, Sampling, Ethical Consideration and Analysis}

To illustrate the effects of policy networks on the management of common pool resources in Mara North Conservancy, Primary and secondary data were collected for both qualitative and quantitative analysis. Secondary data was gathered via reviewing relative literature from journals, books, scholarly publications, policy guidelines and any other documents that was found relevant. Primary data was collected by means of structured questionnaires comprising of closed and open ended questions coupled with interview schedules. Observation was used in confirming certain observable features.

This study used purposive, simple random sampling and stratified techniques to select respondents from the target population. Purposive sampling technique was employed to decide on the general target population. The study area was divided into sections (strata) where respondents were drawn randomly to form part of the sample population. Proximity to the Mara north conservancy was the first criteria for sampling.

According to Welman, Kruger and Mitchell (2005), ethical behavior and ethical considerations are very rigorous when doing research in the field of human undertakings. Ethical considerations in research are concerned with minimizing harm to all participants while in turn boosts benefits in research, (Flick 2009). In undertaking research, the researchers get data from respondents who are usually not part of the inquiry process, (McMillan and Schumacher 2010), so it is vital to consider their wellness in the research process. In order to maintain high ethical standards in this research, quality and integrity of the research was ensured by soughing informed consent from respondents, preserved the anonymity and confidentiality of research respondents, ensure voluntary participation by clearly stating the aim and objectives of the study to the respondents, as well as maintaining high level of independence and impartiality during data collection. I also ensured that collected data is kept with utmost confidentiality. 
Data analysis involved computation of both descriptive and inferential statistics. Descriptive analysis involved calculation of variance, means, and coefficients of variation of the responses without much giving detailed explanation of the values computed. Descriptive analysis therefore, gave general description of the collected responses. Common ways to describe a single variable is through measures of central tendency, frequency distribution tables, and measures of dispersion. This has been depicted in graphs and tables. In inferential procedures, interpretations of values that shall be obtained from descriptive procedures were given. Inferential statistics therefore were used to provide deeper understanding of descriptive statistics. Both qualitative and quantitative methods were used to perform descriptive and inferential procedures.

\section{Discussion}

Despite women legally being able to own land, the informal rules that result in the unequal access of women to tourism revenues were never challenged, and hence, this form of inequality continues to persist in many of Conservancies in the Maasai Mara ecosystem MMWCA report (2018). Likewise, the informal institutional arrangements reflected in the power of the elites continue to exist preventing the achievement of procedural sharing of resources among all members equitably. According to a study of Olaro Orok Conservancy, the most commonly reported negative social outcome was the unequal distribution of benefits to Conservancy households and members Mosimane (2014). Also according to Wainwright, Wehrmeyer, Suich (2013), in some instances unequal distribution of benefits was by large as a result of scarce benefits available to members, this justified why only a small percentage of conservancy members actually received any benefits. It was identified that members relied more on livestock than the tourism revenue generated from the conservancies and shared yearly. Elite capture by both local and extra-locals who received a disproportionate percentage of benefits and continuously engage in exclusionary membership practices, was a major factor in the unequal distribution of benefits within the conservancy (Collomb et al. 2010, Hoole 2010, Kamoto et al. 2013, Silva and, Silva and Motzer 2015). The researcher sought to identify source of income for the households and resource utilization. According to the findings from the field, almost half majority of the respondents intimated that their main source of livelihood is the income generated from tourism activities. A quarter of the majority attribute their source of income as revenue from land lease to the conservancy. Despite most of the respondents being pastoralists, their livestock generated very minimal revenue.

The respondents were further requested to provide information on who determines utilization of income in the household. A majority of the respondents at 50 per cent pointed out that household utilization of income is determined by the Husband, while 30.2 per cent of the respondents pointed out that income utilization is determined by both Husband and wife. The results are summarized in the Bar chart below.

\subsection{Income Source and Utilization in the Household at Mara North Conservancy}

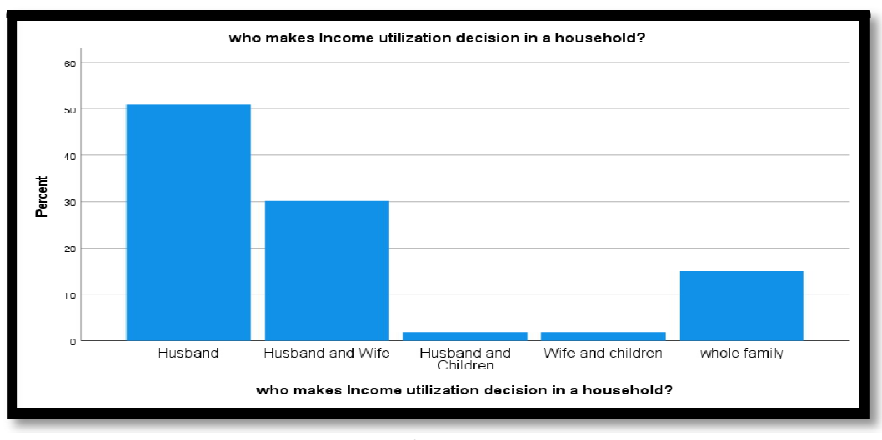

Figure 1

The researcher also sought to understand the power dynamics, network relationships, decision making techniques and stakeholders involvement in decision in the management of the Mara North Conservancy. In a research study carried out to better understand the driving forces behind the policy networks, perceptions regarding the power of actors to influence outcomes at Nashulai Conservancy, the study illustrated that the Grazing Committee and the Board of Governors were unanimously identified as having the highest influence levels. Both groups of actors were perceived as powerful enough to influence distributive equity, specifically regarding payments and resource-use regulations. The next highest level of influence was attributed to the managing company, and to the Landowners Committee, Mosimane (2014). Surprisingly, even though tourists provided the ultimate source of the revenues, their influence over equity outcomes was considered the lowest, mainly because the contractual benefit-sharing arrangement does not depend directly on the number of tourists or the revenue created by tourism. The Tourism Partners were awarded slightly more influence than tourists, because they had an influence on the management of revenue distribution and on contract design.

In these study, majority of the respondents identified the managing company, Seyia limited as being powerful with 50.9 per cent, Board of governors 20.8 percent. The managing company was perceived as powerful to influence contract terms in the conservancy. The third level of influence was attributed to the committee members 17 per cent. Despite the government playing a key role in regulation and developing conservancy policies came in the lowest with 3.8 per cent. 


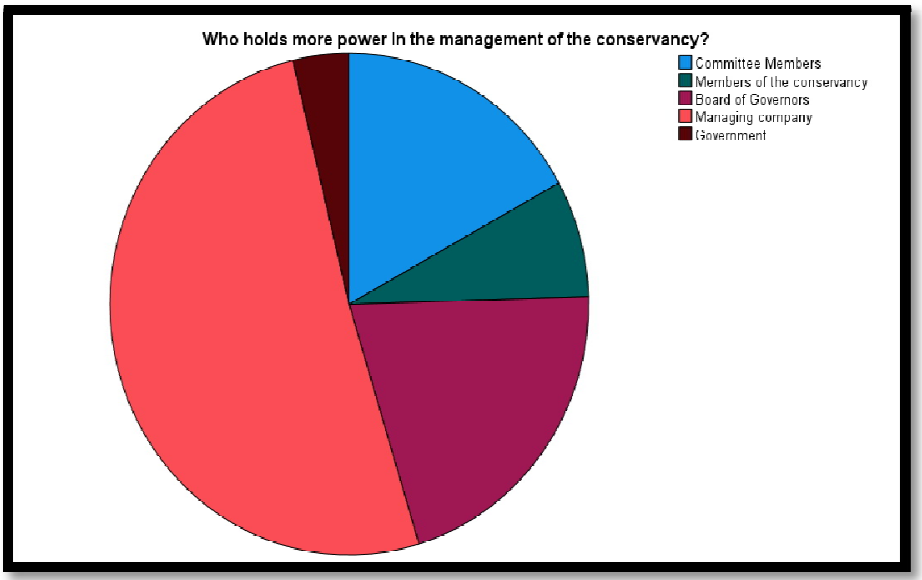

Figure 2

Also from this study at Mara North Conservancy, a majority of the respondents pointed out that individuals and organization attain much more power over others courtesy of their wealth at 47.2 per cent and closely followed by position of influence that one holds both in the community and the country at 39.6 per cent while the relationship between stakeholders come last with 13.2 per cent of the respondents indicating that the source of power is as a result of relationships.

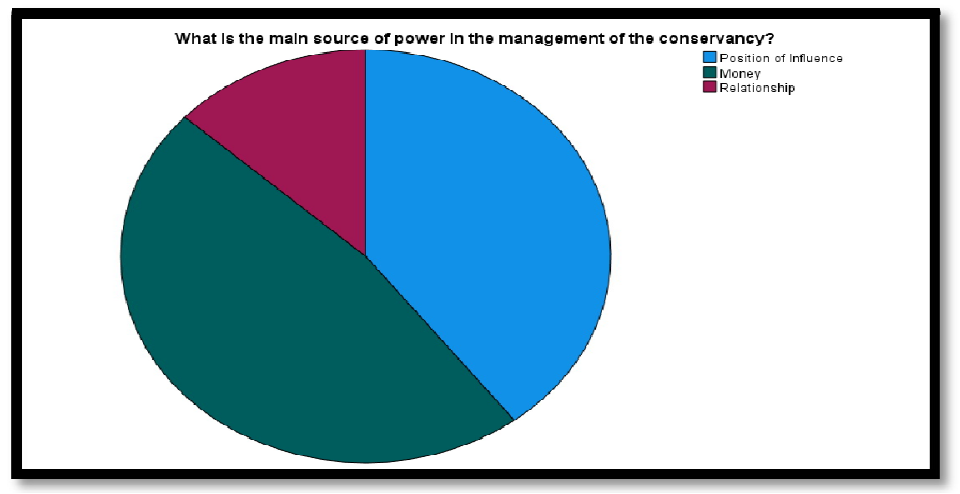

Figure 3

Participation by members of Olare Motorogi Conservancy in making decision is on numerous instances constrained to participation through land committees. Land committee and representatives of landowners hold control over decision making in the interest of members of the conservancy. There is a small proof of conservancy member's participation in deciding the grazing rules, which many of the informants are of the opinion that it was the land committee, tourism firms and conservancy managers who determine grazing rules. As a result of many conservancies establishing controlled grazing plans and conservancy management, made by technical managers, it implied less opportunities for contribution from livestock owners Kamoto (2013). In another study of Naboisho Conservancy many conservancy members said they participated in decision-makingin some way and that was mostly during meetings when called upon to deliberate issues and make their personal opinions: one of the respondents pointed out that:

'it is we as the members and those we have given out our land make decisions'

This comment gives an idea of a common approach to making decision that involved tourism investors and conservancy members. Also these members believed that conservancy members were capable of influencing decisions over the conservancy. Decisions are sometimes made by members, especially when there is a belief that payment are too low, they have an option of saying they do not want the small amount of payment, but want land lease money to be increased. Members can as well decide to talk and stop the misuse of the conservancy and its resources especially those grazing and paid money at the same time. Member of MNC, the respondent in the following quotes, gatherings are pointed out as a means of members of the conservancy being able to collectively negotiate with the tourism firms over the management of the conservancy or make decision regarding livestock grazing collectively. As highlighted, meetings are very crucial for the community members to jointly talk about important topics and this is one of the foremost means by which community members are able to sway decision making.

This study found out from a majority of the respondents that the decision making task is on many occasion made by the committee members and the managing company at 45.3 per cent and 30.2 percent respectively. Board of governors and the landowners contribute the least in decision making at the conservancy at 15.1 and 9.4 per cent respectively. 


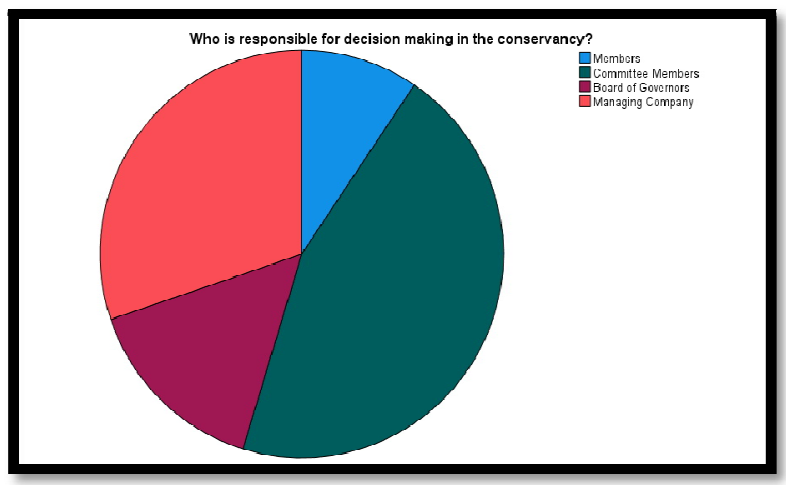

Figure 4

Agrawal (2002) was of the opinion that new commons are a global phenomenon as governments in most of developing nations have gone around to local level common management style for better management of resources. New rules specifying who is included or excluded must be established by the commons as likely resource users and find new ways of sanctioning and monitoring vis-a-vis the new rules. Timothy LeCain, also argued that institutions that regulate access co-evolve with the material world and are in many ways a 'mix of humans and things, culture and matter, society and technology'LeCain (2015). According to a study by NRT (2015) at Lewa conservancy, it was argued that the management of CPRs are symbolized by the upcoming character of institutions. They are moulded by ongoing negotiation between state officers and local members and among local members bringing on board new ideas of rules and regulation and how best to share resources without having wrangles.

The research sought to understand if the respondents are aware of any existing rules at the Mara North Conservancy. As a result of the study, a majority of the respondents at 71.1 per cent are aware of the existing rules while 28.3 per cent of the respondents are not aware of the existing laws and rules.

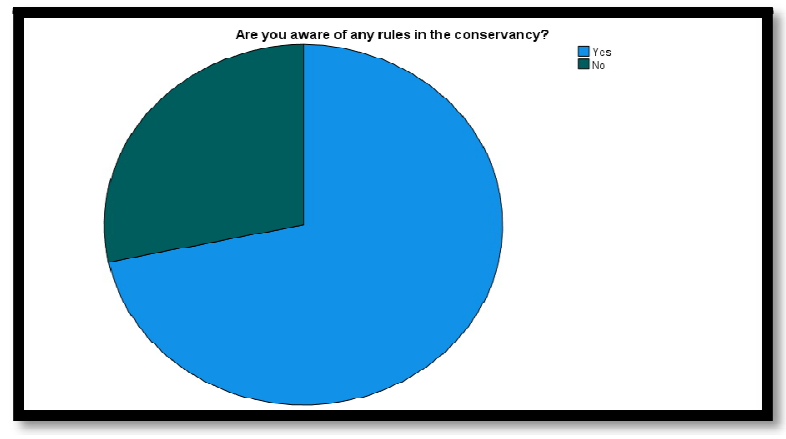

Figure 5

Illustration of power possessed at community level in making and in imposing grazing rules, inventiveness in coming up with the conservancy and formulating the rules come from the tourism firms together and persons from both inside and without the community. In investigating how and whether landowners have an input in decision making in conservancy management, we take a keen look at formulation of rules and laws at the conservancy. Access to livestock grazing has been completely changed by the conservancy, and is a crucial worry for locals of the community. In fact, grazing became the most contended concern that was raised during interviews by community respondents, and the starting point of conflict among the conservancy and the community. By signing lease agreements landowners agreed to observe certain conservancy regulations. The lease agreement stated that the landowner shall not 'use or permit the Premises of any part thereof to be used to graze livestock save in accordance with a grazing management plan set out by the Tenant' Osano et al (2013). The prerogative in writing stated that grazing management plans set out by conservancy managers and tourism firms must be followed by the landowners. The plans dictated where and when, livestock are to be allowed to graze inside the conservancy. Many members never considered themselves to be crucial in setting the rules that govern conservancy. They mainly saw it as the conservancy management, tourism firms or land committee who decide on grazing rules:

The man in charge of the conservancy rangers goes round telling members the part they should graze and the part they shouldn't. members don't just graze cows anywhere unless a report is received from the conservancy rangers or the committee members'

This was also confirmed by another Elder, a member of MNC, community interviewee

the tourism company has been given a chance to lead the conservancy and he is the one that has made rules that govern how we coexist in the conservancy'

In a study carried out at Naboisho Conservancy indicates that the committee discusses themselves and later come back to inform members the decision made. These implies little participation in decisions determining management of the conservancy, but instead members are informed of the fact of any decisions made by the conservancy management or the land committee. Definitely, setting of rules in the conservancy was by large made by the land committees and the 
conservancy managers, with roles in rebuking illegal grazing, hannelling of information to landowners and lessen conflicts between livestock keepers and the conservancy.

Conservancy regulations are watched over, enforced by conservancy rangers and supervised by the conservancy management. Grazing of herds in the conservancy and at non-stipulated times by owners attracts a fine. Livestock are driven to the ranger gate or post and confiscated till a penalty is fully paid for. wrongdoers may even be given community service or imprisoned (Naboisho 2013).There were equally much complaints from community members over mistreatment of herders by rangers (Bedelian and Ogutu 2017). It was noted that penalties were rampant and constitute a high cost to households. This was much intensified during drought times due to the considerable pressure from livestock grazing and conservancies trying to maintain grass for wildlife.

In the household interviews, the respondents were asked of who formulates rules and laws in the conservancy. Half of the respondents thought that members and Board of governors have an upper hand in formulation of rules and laws to be applied in the management of the conservancy.

According to Killick (2010) centralization is concerned with the maintenance of a well-coordinated system of conservancy management policies regulated by the central government actors. National government through the ministry of Tourism and Wildlife argues that it's better placed to implement far-reaching policies and programs to address adverse interests of the citizens KWCA Report (2018). Intentions to devolve resource management were meant to empower local communities, However, of main concernis who gets represented, and who make the decisions, is not so clear. The main concern is whether actors receiving power are really responsible to the locals (Ribot 2006). Individuals receiving power need to be held responsible at the local level in order to broaden participation as well as ensure representation of local people in meaningful decision making Agrawal and Ribot (2006). Transfer of meaningful power to democratically elected members and decentralization of decision making will result to good governance at the local level Ribot (2006). He further pointed out that there is need for regular and competitive elections as mostly non-elected officials may not be responsible. Secure tenure of land gave much power to the less fortunate to negotiate and secure benefits from tourism firms (Ashley and Roe 2002), it also gave members a sense of ownership of the conservancy (Naboisho 2013). These also helped strengthen the rights of members in collaboration, as well as make it possible for bargaining to take place between the tourism firms and the members. Example, it was possible for members to negotiate the length of the lease agreement to not go beyond 5 years. However, in signing off land to a conservancy effectively gave away legitimate rights of use, and takes land out of the control of landowners for the length of the lease contract. It was common for conservancy members to talk about 'giving out their land' when becoming a conservancy member, an indication that power and control was handed over to the tourism firms in the process to decide on the management of the conservancy.

In view of the above, a minority of the respondents are of the opinion that the national government at 9.4 per cent was involved in making decisions while 11.3 per cent of the participants believed that KWS is involved in the management of the conservancy. It was also pointed out from the study that the involvement of both the ministry and KWS was only to help in policy formulation.

Decentralization has been deployed by many governments as a mechanism for broadening participation of local people as active agents in management, and thus in governance processes (World Bank 1996 cited by Muna 2016: 66). Therefore, by decentralizing the management of conservancies, there is an inclination by the locals to belief that their participation in committees will have them potential and power to decide the nature of services that will be provided. Participation in management process means that networks influence decision making, have control over development initiatives, and resources over the issues that affect them. Ribot and Oyono (2005) argue that decentralization initiatives are ostensibly devised to enfranchise local people through rights and representation in local public decision making. In view of the above, the majority of the respondents in the study revealed that landowner's committee at 47.2 per cent was much involved in decision making and it was the most crucial department in the management of the conservancy.

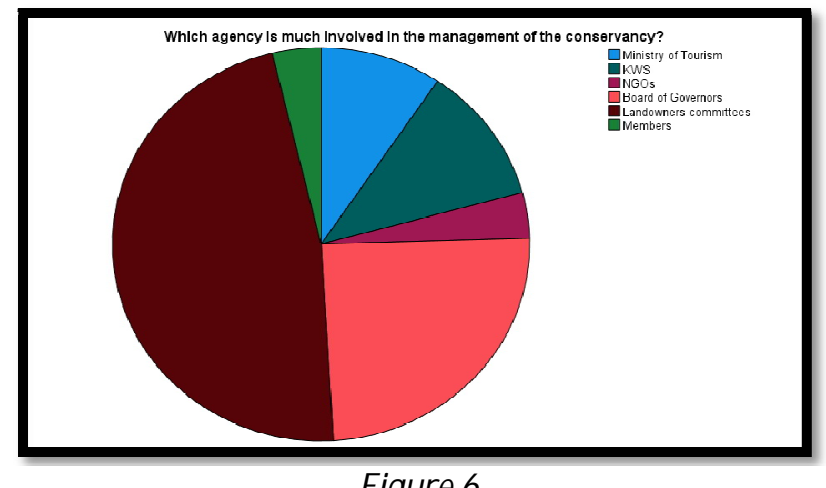

Figure 6

\subsection{Cause of Conflicts}

The formation of conservancies has in few instances had unplanned consequences of stimulating conflicts, Campbell et al (2015). Examples of this is the Sera Conservancy in Samburu, where traditionally the Samburu, Borana, and Rendile shared pasture during the dry season. With the creation of the conservancy, only Samburu scouts were able to access the land, thus leading to conflicts. In Naboisho (2013), the respondents are of the view that the conservancy was contributing to conflicts within the community, due to the curtailment on livestock grazing and the movement of settlements. As it was put by the respondent: 'It has completely brought conflicts because if for example you are living on 
someone else's land and he sells it, you will be moved, at any time. likewise, if there is someone else living on someone else's land, he will also be moved in the same way.' another respondent pointed out thatit is a problem when the livestock cross the border across to other conservancies and are caught, that also brought conflicts because of the fine. The comments suggest that there was an increase in conflicts amongst members over access to land for grazing and settlement. Again, the fact that conservancy payments only benefited certain personsat Koyiaki Conservancy and not the entire community, meant that the conservancy will generate inherent conflicts which only magnify this.

In the interviews conducted at Mara North Conservancy, leadership conflicts were a major direct cause of conflicts. In election for new office holders, nepotism, favouritism, corruption and rigging are reported to ensure one ascends to the conservancy leadership position. In a Conservancy study, 41.5 per cent of the respondents reported leadership wrangles being the main cause of conflicts at the Conservancy, a 26.4 per cent attributable to resource sharing at the conservancy while 15.1 per cent was attributed to grazing land.

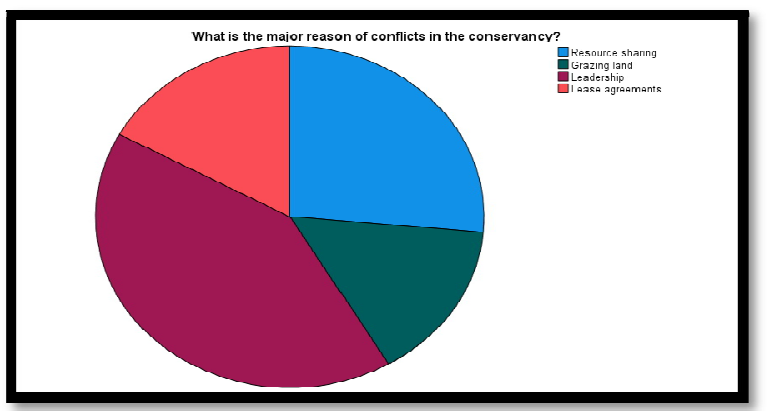

Figure 7

\subsection{Information Technology and Communication in the Management of the Conservancy}

\subsubsection{Access to Clear, Valid and Relevant Information}

Crosby (2002) argued that information sharing is aimed at keeping stakeholders informed. As a result, availability of information to the networks at the local level will enable them make informed decisions, build legitimacy and builds transparency. Kim and Schachter (2013) also argued that sharing of information was an empowerment process as it enables citizens to deliberate, negotiate and make informed decisions over the distribution of common resources. He equally pointed out that conservancy meetings were the major avenue of bringing together conservancy landowners, often along with tourism investors and conservancy managers, to talk about conservancy related issues. Meetings are a means of communicating to members on conservancy matters and a forum in which conservancy land committees and managers are able to bring up issues to talk about with conservancy members. Meetings are also a major channel by which all members directly contribute to conservancy management and decision making. Meetings therefore are a crucial channel of communication between various networks involved in conservancies, coordinating activities, making decisions and sharing information. It is through these meetings that key collective actions were made. Through these meetings all conservancy members were invited to attend, such as annual general meetings (AGMs), which was mainly one of the few opportunities meant to bring together all members of the conservancy (Bedelian and Ogutu 2017).

Ordinarily such meeting was held only once a year because it was practically difficult to bring people together due to the large number of dispersed members. It was identified as a concern for the conservancy members. It was indicated in a report of a meeting attended by conservancy members where members of the conservancy, like Olare Motorogi, reported attending more meetings than members of other conservancies (MMWCA 2018). Meeting were called for as need arose, also organised on an ad hoc basis, as well as in discuss pressing concerns, inviting all who are able to attend. According to one respondent

'During the meeting I attended at MNC, a variation of different concerns was talked about regarding the conservancy. Meetings started with a number of set topics to discuss as per the agenda, but usually wandered off this as members raised any issues of concern. Meetings were a place to discuss potentially contentious issues and try to mediate and resolve any conflicts.' Meetings ordinarily were chaired by the chairman of the land committee, and also involved the land committee members. The chair of the meeting was tasked to tryto reach an agreement on concerns on the agenda, although this could not always be the case. Members were given opportunities to speak and bring up points of concerns which they could stand and speak up. Failure to reach consensus or decision not reached will lead to adjournment of the meeting to another day. The land committee as well as the conservancy managers must be present in meetings, however, tourism operators only appear depending on the agenda of the meeting.

In a study carried out at Olare Orok Conservancy, conservancy members spoke of insufficient communication, lack of meetings and information between members and conservancies. In Naboisho Conservancy, members reported to have only attended meetings meant to signing up to the conservancy with some claiming they were not fully informed about the conservancy before signing-up (Bedelian and Ogutu 2017).

Even though local meetings were organised in the area and around the conservancy, locals never knew or even understood lease and conservancy concept at first hand as a result of limited time. It was equally identified that less women attended conservancy meetings. The only women to have attended conservancy meetings were conservancy members who had inherited land from their spouses. Even though the wives of conservancy members were invited to attend meetings, very few did attend. In the study carried out, few women reported to have attended a conservancy 
meeting. They intimated that they knew very little about conservancies since they were not members and did not attend conservancy meetings. Women received information about the conservancy from their spouses who attended meetings. Women not attending meetings has been illustrated earlier quotes, where women pointed out that they knew little in relations to conservancies as there was no involvement. Men hold titles to land while women don't thus make them conservancy landowners which give them a leeway to attend conservancy meetings. In this regard, women seem to be largely uniformed about conservancies.

In the study carried out at Mara North Conservancy more than half of the respondents pointed out at 56.6 per cent that they are not able to access valid, and clear information while a minority of 43.4 per cent are of the opinion that they are able to access information when they need it.

\subsubsection{Access to Valid and Clear Information at the Mara North Conservancy}

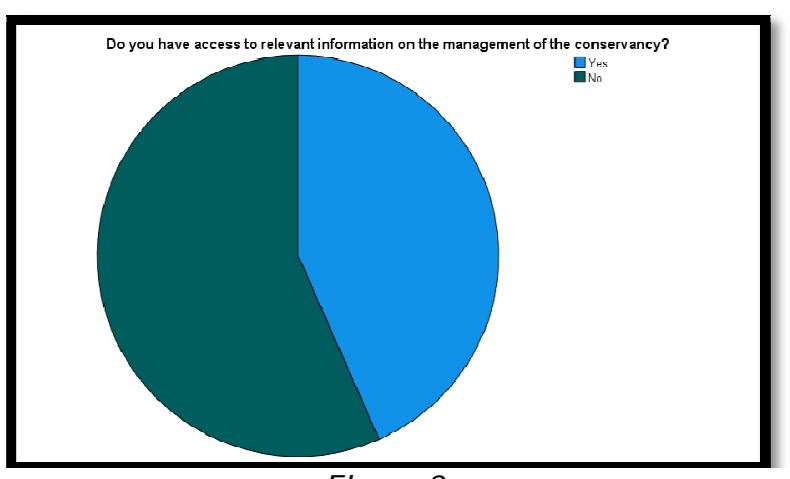

Figure 8

\subsection{Political Ecology Analysis of Networks}

This analysis was used to summarisekey findings related to the conservancy policy networks among the various networks. Taking into consideration the range of different interest groups and the means they interrelate, this helps to clearly understand why different groups get involved or not in the way they do. A study of the networks shows a number of frequent participating interest's groups. Table 4.1 outlines the various groups of interest involved in or affected by the management of the conservancy, and indicates their source of power and their main interest and concerns in relation to networks. Although there will be diversity within groups, each group is simplified to portray the dominant area of interest and source of power. Individuals can also belong to more than one group.

\begin{tabular}{|c|c|c|c|c|}
\hline $\begin{array}{l}\text { Interest } \\
\text { Groups }\end{array}$ & $\begin{array}{c}\text { Influence at Point of } \\
\text { Starting }\end{array}$ & $\begin{array}{c}\text { The Source of } \\
\text { Power }\end{array}$ & Interests & Concerns \\
\hline Tourism firms & $\begin{array}{l}\text { Very strong as it } \\
\text { introduces the concept } \\
\text { of Conservancy }\end{array}$ & $\begin{array}{c}\text { The firms control } \\
\text { capital, tourists, } \\
\text { legal and } \\
\text { marketing } \\
\text { structures. }\end{array}$ & $\begin{array}{l}\text { Main interest is profits, } \\
\text { long-term investment } \\
\text { security, high quality } \\
\text { tourism products. }\end{array}$ & $\begin{array}{l}\text { It excludes livestock and } \\
\text { settlement to enhance } \\
\text { tourism product, land } \\
\text { sales and subdivision, } \\
\text { sustainability of funding }\end{array}$ \\
\hline $\begin{array}{c}\text { Land } \\
\text { committee } \\
\text { members }\end{array}$ & $\begin{array}{l}\text { Strong and some very } \\
\text { key members refine, } \\
\text { mediate concept and } \\
\text { communicate }\end{array}$ & $\begin{array}{l}\text { They hold political } \\
\text { and local } \\
\text { leadership } \\
\text { positions. }\end{array}$ & $\begin{array}{l}\text { Main interest is to maximize } \\
\text { profit, maintain political } \\
\text { power and maximize } \\
\text { lucrative tourism based } \\
\text { ventures. }\end{array}$ & $\begin{array}{l}\text { Maintain sphere of } \\
\text { influence and power. }\end{array}$ \\
\hline $\begin{array}{l}\text { Conservancy } \\
\text { members }\end{array}$ & $\begin{array}{l}\text { Though informed of the } \\
\text { concept they are weak. }\end{array}$ & $\begin{array}{l}\text { collective action } \\
\text { and Title deeds to } \\
\text { conservancy land. }\end{array}$ & $\begin{array}{l}\text { Maintenance of livestock } \\
\text { elsewhere and Income } \\
\text { diversification. }\end{array}$ & $\begin{array}{l}\text { little transparency of } \\
\text { investor profits vs } \\
\text { community revenues, and } \\
\text { Lost livestock grazing } \\
\text { space. } \\
\end{array}$ \\
\hline Women & $\begin{array}{l}\text { There is no evidence of } \\
\text { involvement.Very weak } \\
\text { group. }\end{array}$ & $\begin{array}{l}\text { Limited to what } \\
\text { spouses give. }\end{array}$ & $\begin{array}{l}\text { Maintain livestock and milk } \\
\text { production }\end{array}$ & $\begin{array}{l}\text { Lost livestock and milk } \\
\text { production. }\end{array}$ \\
\hline $\begin{array}{c}\text { County } \\
\text { Government }\end{array}$ & $\begin{array}{l}\text { Involved in issuing of } \\
\text { permits to private } \\
\text { investors making it a } \\
\text { Strong group. } \\
\end{array}$ & $\begin{array}{l}\text { Legal, and } \\
\text { management } \\
\text { structures. }\end{array}$ & $\begin{array}{l}\text { Revenue streams; Maximize } \\
\text { revenue collection to } \\
\text { finance budget. }\end{array}$ & Loss of revenue. \\
\hline $\begin{array}{c}\text { National } \\
\text { Government }\end{array}$ & $\begin{array}{c}\text { Strong as it controls } \\
\text { policy formulation } \\
\text { processes } \\
\end{array}$ & $\begin{array}{c}\text { Legal, } \\
\text { management } \\
\text { structure. }\end{array}$ & $\begin{array}{c}\text { Regulation to ensure } \\
\text { wildlife is not lost, Maximize } \\
\text { Revenue generation. }\end{array}$ & Loss of wildlife \\
\hline $\begin{array}{l}\text { Board of } \\
\text { Governors }\end{array}$ & Strong-Agenda setting & $\begin{array}{c}\text { Oversee the } \\
\text { operations } \\
\text { management of the } \\
\text { investor company }\end{array}$ & $\begin{array}{c}\text { Maximize leadership roles, } \\
\text { Maintain lucrative tourism } \\
\text { ventures. }\end{array}$ & $\begin{array}{c}\text { Influence the management } \\
\text { decisions of the } \\
\text { conservancy }\end{array}$ \\
\hline
\end{tabular}

Table 1: Different Interest Groups, Influence at Start Up, Sources of Power, Interests and Concerns 
The political ecology analysis shows that rather than a homogenous community with common goals and shared norms, Mara North residents are socially differentiated in terms of livelihood interests, political power, age, status, social position, wealth, and gender. This differentiation creates a variety of conflicts and interactions that influence how people participate in and benefit from the network. It highlights how power relations between the community and within the community, Government and tourism firms play out to decide who participates in and benefits from conservancies, and by how much.

\section{Findings of the Study}

\subsection{Power Dynamics in the Policy Networks}

Power is a critical factor that influences every component of the framework and is incorporated as feedback loops to represent the dynamic relationships that condition relationship and policy network outcomes. Although we acknowledge the complexity of the concept of power, as famously shown by Foucault (1982), we refer to power here as one actors control of the decisions, actions, thinking and environment of others (Bryant 2002). The existing arrangements of network actors are therefore considered to be a product of embedded power relations within and between various institutions over time. Networks can reconfigure power relations by allocating different actors including private scheme implementers, government agencies and various groups of local communities' influence over participation in, and benefits from conservancy, irrespective of their formal rights. Power can therefore transform and or reinforce relations between actors by affecting the wide range of social relations that influence equity outcomes (Ribot and Peluso 2003).

Of particular importance to this study is the power that the central government retains in KWS and the upward accountability that results KWCA report(2018). The central government retains powers of oversight, advising, and arbitration. Additionally, central government retains much influence through the Kenya wildlife Conservation Association, which is ascribed an advising mandate according to KWS regulations. This Association is comprised largely of central government appointees, including the County Commissioner who is the chair of the County Wildlife Conservation and Compensation Committee (CWCCCs) and this disregards the competitive process of recruiting the chair. Despite their official role as merely advisors, these central government authorities often influence conservancy trajectories significantly and sometimes fully dictate to them, thus recentralizing the power supposedly devolved to the conservancy that's according to a report by KWCA (2018). The involvement of the County Government in developing of policies, involvement in the day to day operations and influence in decision making in the management of the conservancy was so visible from a layman's something that was all confirmed by the County executive in charge of Tourism.

Respondent 6:

The County Government Act, 2012 gives effect to chapter 11 of the constitution which provides for the county government's powers, functions and responsibility to deliver services. It mandates the County government to make legislation for the management and exploitation of county resources which conservancies is one of the resources'

From these study, majority of the respondents pointed out overwhelmingly that the Managing company (Seyia Limited) holds immense power and was closely followed by the Board of governors while members who are also landowners hold less power.

The managing company is so powerful that it can conceal lease agreements from members and even in some cases renew lease agreements after expiry of the previous one without much involving all the members'.

According to our respondents, the company is more powerful because of the financial power it has over other stakeholders. According to a report from Maasai Mara wildlife conservancies (2019), it has acknowledged that there is need to establish strong governance structures and building capacity. One of the landowners indicated that the conservancy was created after amalgamating 12 other trust lands which was done in a hurry leading to an ineffective structure.

In determining the leases, the managing company has an upper hand in negotiation of lease fee because of its power.

\subsection{Decision Making and Involvement of Policy Networks}

According to a study from respondents on Kasigau Conservancy in Kenya, institutional arrangements described Wildlife Works Carbon Trust, the project entity that distributes overall revenues to local communities throughout the project area. The Locational Carbon Committees, which consisted of publicly elected community members, were established in each administrative location to prioritise and allocate carbon benefits through community projects. The Locational Carbon Committees collaborate with local Community-based Organisations to identify required projects. Communities were invited to elect Locational Carbon Committee members and to submit proposals to the them for desired projects to be implemented from carbon funds. Perceptions of procedural equity in Kasigau was captured by the respondents' perceptions of their access to local-level decision-making mechanisms and dimensions of accessibility and responsiveness to community.

Perceptions of resource sharing in Mara North Conservancy pointed to an elaborate decision-making process that involved elections and nominations of community representatives for the Landowners Committee and the Grazing Committee. However, respondents expressed reservations regarding the extent of meaningful participation, which is an important component of resource sharing. For instance, respondents lamented about poor access to information from the Grazing Committee regarding designated grazing locations and general conservation management. After the project inception meeting in 2009, there was an expectation that meetings would be held annually and it was most concerning for 
respondents that this expectation was not met; only one general meeting was held in 2014 (Respondent 4 and 5). Respondents, therefore, perceived of the mechanisms for ensuring sharing of resources as inadequate, failing to provide sufficient room for meaningful participation.

It was also important to study the decision making and involvement of other networks in the conservancy. From the findings, the Committee members bowed the biggest responsibility of making decisions on the management of the conservancy, While the managing company coming in second. The researcher also sought to find out how best to enhance decision making, a majority of the respondent felt that the input of other stakeholders was necessary. There was a feeling from a majority that if the committee members involved members, managing company and government, it would reduce conflicts and enrich decision making.

According to a study at Olchorro Oirowua Conservancy on collaborative approaches, it was identified that women were excluded from formal land ownership, the extent that women fromthe Conservancy, could benefit from resources depended on intra-household distributional dynamics. The research has shown that the subdivision process which was tied to conservancy membership reinforced existing gender inequities (Mwangi' 2007b). This was affirmed by Respondent 3 (Household interviewee)

We still have a long way to go. Women in Maasai Mara conservancies are yet to know their land rights. They do not have information on land ownership and inheritance. In conservancies where landowners receive conservation lease fees, women are hardly involved in signing spousal consent, while Kenya's marital and property laws affirm spousal consent in land ownership. It is time we empowered the women in conservancies to know and stand up for their rights in order to participate effectively in conservancy decision making'.

Land ownership plays a central role for determining sharing of resources in the conservancy, not only because payments are often linked to land ownership but also because land ownership increases an actor's bargaining power Wunder (2013). Looking at the Mara North case, our results confirm that resource users who have knowledge of ecosystem service markets have more bargaining power, also if intermediaries are involved and as a result of equal distribution of land, bargaining power led to equitable distributional outcomes. In the Mara North Conservancy, negotiations with intermediaries demonstrated a sound knowledge by community members of the economic potential of the area based on an understanding that tourism generates incomes. This result is in line with the fact that the Board of Governors was identified in the study to have more influence over the distributional outcomes than the implementing company. This finding reflects the perceptions that the landowners have sufficient leverage to achieve outcomes that are acceptable to them.

\subsection{Innovation and Change}

Lewa Conservancy succeeded in the development of innovative working relationships, However, issues of authority to make decisions were encountered in the process, probably as a result of the arrangements of national and county officials. This necessitated the need to bolster communication of various workgroups and even departments and assess their position in the negotiation table. As a result of high levels of trust built, decisions from negotiations were taken quickly while ensuring the required flexibility of the process. A similar approach in Kajiado County conservancies that agreed on Management plans and allocation resources in the early 2000s saw success even though challenges encountered (Dale et al.).

In governance, researchers play a critical role in steering innovation in management of CPRs Daniel et al. (2014). Ensuring adequate knowledge and consideration of innovation and investment across all areas, coordinated research bodies and brokers may be required in order to gain maximum benefits over larger geographical areas. rather than relying on individual researchers driving innovation in one area around their own interests. Ordinarily research programs need to be linked strongly community needs or end-user, with these stakeholders helping to set the research priorities and helping to follow the research through participatory research set-up Barret au (2010)

Respondent 4

'there is need to have direct link made to the use of this research to improve innovation and inform the decision making processes in the management of the conservancy. People come to the Mara every now and then conducting research but we never see the fruits of it. The community must start to benefit from this findings going forward'

From the study, majority of the respondents pointed out that the conservancy still rely on public forums to pass information to other stakeholders. With digital revolution throughout the world, its crucial for the conservancy to adopt more innovative means of ensuring that all its stakeholders can get information in a timely manner. Though from my personal observation, it is crucialto mention that within the conservancy, there are Karen Blixen hospitality school and Koyiaki guiding school which has gone along away in improving employee's capacity and provide superior services to the stakeholders.

\subsection{Governance Processes}

Governance processes can be a very big issue and most of the time forgotten and overlooked by organizations. It basically helps to amalgamate management processes initiatives within rules and guidelines and standards that all go along a common goal. The main purpose of governance process is to prevent isolated and disconnected management process. The researcher therefore sought to study formalization, centralization and decentralization as well as specialization in the management of Mara North Conservancy. 


\subsection{Formulation of Rules and Laws in the Conservancy}

Institutions formulate unwritten and written rules that influence human behaviour. North (1990: 3) defined institutions as the rules of the game that structure economic, political and social interactions. Rules and laws are critical for management of the conservancy majorly as they regulate human interaction with common resources. Many rules and laws that influence human interaction are non-formal and created, communicated, and enforced outside of officially sanctioned channels Helmke and Levistsky (2004). Formulation of rules and regulation is very critical since it safeguards the lawful rights and interest of the policy networks. It also prescribes the obligations, provide corresponding rights and the means by which the realization of such rights are safeguarded.

At Shompole Conservancy, the existence of rules and laws has been applauded to have reduced illegal grazing of cattle in protected areas. Also the existence of laws has brought about collision between livestock keepers and game rangers and increased conflicts in the conservancy. Respondent 1 pointed out that;

the biggest bond of contention in the conservancy is the Leadership wrangles where the majority believe the political leadership and community elites are having undue advantage in their expense. Also the grazing areas has been given to certain powerful county officers who are not members of the conservancy contrary to the conservancy rules stipulating that only landowners are allowed to graze in the conservancy.'

From the study it was evident that a majority of the respondent were aware of that there exist rules and laws in the management of Mara North Conservancy. It's equally important to point out that few old people of the society don't have an idea if such rules exist. Majority of the respondents also believe that laws and rules are formulated by members and pass it to the managing for enforcement. Livestock grazing at the conservancy is managed strategically by four established grazing committees assigned to each of the conservancy zones. Landowners are the only ones allowed to graze their cattle in the conservancy. This form of management has been applauded for its effective control of grazing spaces and the livestock number at the conservancy Ostrom (2006). However, a majority of the respondents pointed out that conflicts arise mostly as a result of leadership wrangles.

To achieve legitimacy in the conservancy, it is not sufficient that the distributional outcomes are considered legitimate. This finding is in line with previous research that indicates that conservancy rules need to be designed and implemented in an inclusive process to be considered legitimate Hand Sikor (2015). Likewise, management mechanisms should be justified according to social norms and characterised by consent regarding claims to authority over common resources and their benefits Jentoft (2000). Non-inclusive procedures in policy networks design can erode the sustainability of the objectives and potentially lead to increased conflict Luttrell (2013). Some researchers, therefore, argue that striking the balance between efficiency and fairness is critical to achieve meaningful outcomes Lemoina (2015), while other researchers rightly recognise that competing considerations of fairness make designing equitable sharing of resources considerably challenging Narloch (2013).

\subsection{Centralization and Decentralization}

One of the most prominent contradictions of today's conservation is centralisation and decentralisation, Agrawal (2006) aptly conceive it, 'recentralising while decentralizing'. Ribot (2002) defines decentralisation as when a central government formally transfers power to actors and institutions at lower levels in a political-administrative and territorial hierarchy. With the escalation of efforts to roll back governments and incentivize rural inhabitants, decentralisation has become instrumental in today's conservation projects Ribot(2005). At the same time though, for a host of licit and or illicit reasons, central governments commonly deploy mechanisms to inhibit decentralisation, retain control and discipline citizens in line with its own, as well as global investors' interests, and includes formal and informal institutions that constrain and limit decentralising efforts Ribot (2006).

According to a study on Carbon credit in the Coast most respondents felt that governance processes was adequately catered for because not only were the Locational Carbon Committees publicly elected from within each of the respective locations, the communities are also invited to elect Locational Carbon Committee members in accordance with affirmative action principles regarding gender representation. Therefore, unlike in Mara North Conservancy, the results reveal that equity was actively pursued through what were typically considered meaningful elections and regular meetings which were attended by both men and women. However, several governance challenges were highlighted. Examples included county representatives who attempted using CBOs for political mileage and cases of patronage between Locational Carbon Committees and CBOs that contributed to delays in project implementation. To safeguard against corruption and misuse of funds, procedural equity was enhanced by the implementation of Standard Operating Procedures rules governing Locational Carbon Committees and CBOs formulated in collaboration with Wildlife Works which were subject to annual amendments intended to limit the likelihood of repeat corruption incidences.

According to Respondent 5 and 7;

'meetings are rarely called for to allow members air out issues, seek information and clarity on what the managing company and board of governors in the conservancy are doing. We don't have access to our lease agreements and we are therefore not sure if there is collusion between the company and elites in the society to continue with the unfair sharing of resources. We need frequent participation'

It is important to note that although devolution is a defining principle of Conservancy management, a study on the Selous Conservation Programme in Tanzania, it was originally designed to devolve responsibility and authority to local communities, yet the establishment of an extra bureaucratic layer, similar to that of Zimbabwe's CAMPFIRE program, which made decisions effectively on behalf of local communities but did not serve their interests Songorwa (1999). From the study, on the Mara North Conservancy it was equally noted that the central government still have influence on how the conservancies are managed. 


\section{Respondent 2;}

the national government still controls how we manage our own affairs in the conservancy, just to mention the recent push the Cabinet to have us adopt the Maasai Mara Management plan, the County commissioner being the Chair of Community wildlife committee without going through the competitive recruitment processes. The Cs has also reduced the functions of the committee from 10 to 3'.

Similarly, in Malawi, the national government came up with the Forest Policy Act in 1997, with the intention of devolving rights and authority regarding forest management to local Village Forest Areas through village natural resource Management Committees, yet few Village Natural Resource Management Committees that was actually given authority to manage and enforce rules in forest governance because all actions had to be approved by the national-level minister Kamoto (2013).

This study has identified that the quality of leadership at the conservancy determine the implementation of key projects, sharing of resources, conflict resolution mechanisms, transparency and sharing of information and their political will is in accomplishing the above issues. It has also emerged that despite conservancies being private entities, both national and county governments are much involved in developing policies that direct how conservancies are managed.

\subsection{Information, Communication and Technology}

Perceptions of policy networks in the Mara North Conservancy pointed to an elaborate decision making process that involved elections and nominations of community representatives for the Landowners Committee and the Grazing Committee. However, respondents expressed reservations regarding the extent of meaningful participation, which is an important component of information and communication. For instance, respondents lamented about poor access to information from the Grazing Committee regarding designated grazing locations and general conservation management. After the project inception meeting in 2009, there was an expectation that meetings would be held annually and it was most concerning for respondents that this expectation was not met; only one general meeting was held in 2014 .

Respondent 7;

'the information provided to us is not clear and always comes late after an action has already been taken by those incharge of the operation of the conservancy. We haven't had meetings for years now. We need regular meetings, participation in management and use of various media platforms to reach out too many members in place of public administrators and public barazas'

This study also identified that majority of the respondents acknowledged existence and even access to relevant of information on the management of the conservancy. However, a majority of them still believe that the information at their disposal is insufficient and not comprehensive enough to allow make informed decision on many matters at the conservancy. Further, information provided according to this study, is that the available information provided was never clear nor valid. Information sharing among stakeholders was through public forums as depicted from the findings of this study. According to Ostrom (2002), governing the commons in a multi-level world requires novelty and innovation. Recognizing the complex nature of the management of CPRs, it draws attention to social and ecological properties not amenable from conventional top down decision making and this include feedback, innovation and change.

\section{Conclusion of the Study}

In a globalised and rapidly changing world, processes of making decision is related with the implementation, monitoring and development of public policies are becoming increasingly complicated. Governments and government departments have been identified enough governance structures, power or resources that are required to adequately respond to public policy challenges under their responsibility and effectively govern their jurisdictions. Meaning they are supposed to work with, seek the aid of other agencies from non-government organisation, private, public or community spheres, and often across a range of sectors for them to achieve their set objectives. Understanding and managing issues related to governing across a range of boundaries are thus paramount to achieving positive public policy outcomes.

In the Mara, conservancies constitute a collaboration between tourism investors and the local landowners. The assumption is that the arrangement of land on the side of the community combined with the capital, market access and tourism expertise provided by the tourism investors forms the basis of a joint management venture and benefit sharing arrangements. These forms of collaborations are the upcoming trends in Kenya, and other parts of Africa (Mburu and Birner 2007). Partnerships are seen as important to the flourishment of conservation projects (Seixas and Berkes 2010). However, community-private sector partnerships can raise intricate concerns over ownership, rights and governance (Adams and Hutton 2007). Scholars argue that in the presence of locally initiated institutions expressing explicit legal rights over land and resources, co-managed ventures between communities and the private sector are more likely to work (Ashley and Jones 2001). Mavhunga (2007) argued the importance of clearly identifying group motive and purpose of collaboration. There will always be diverse motives from different participating partners in a project. Networks may be highly mismatched in terms of power, wealth, access to information, and education (Mavhunga 2007). Utmost caution must be taken into consideration to ensure that limited understanding and the lack of experience of the tourism industry on the part of communities does not lead to power imbalance where a passive role is taken by the community (Ashley and Jones 2001). Mavhunga (2007, p442) likens the unequal power relations typical within conservation partnerships to a partnership between a rider and a horse, 'where some shoulder the burden whilst others enjoy the scenery'. It is thus important to be aware of any power imbalances amongst networks. Genuine collaborations should must bring communities actively into the management process, rather than work on a command-and-control style (Berkes 2004). This requires a commitment to sharing responsibilities, rights, decisions, and also risks, amongst networks, which requires close transparency, collaboration, and accountability between the different networks involved (Berkes 2004). 
Lastly, Successful strategies seen in the study included flexible management practices and a range of interorganisational mechanisms to drive the governance system and implementation of its decisions; intergovernmental and government community networks with non-hierarchical structures that could involve rotating chairs and joint objectivesetting decision-making; and trust building through ongoing and regular engagement and listening to others. On the other side, challenges that could lead to failure included instability in authorising environments, including changing philosophical positions and structures in ways that do not help maintain relationships important for advancing the conservancy, and the requirement of significant resources for collaborative approaches that may or may not finally provide value for money in terms of results, both politically and practically.

\section{Acknowledgement}

I would like to acknowledge God's favor for the far I've come. It hasn't been an easy journey but because of his grace, favor and care he has granted unto me throughout the years of conducting this study.

Special dedication and thanks to my supervisor, Dr. Wilson K. Muna for inspiration, hard work,efficiency, commitment and the constructive criticism. I'm forever grateful to the respondents and community from the Mara North Conservancy who contributed their insight into collection of this data. Special thanks also goes to my classmates for the moral support and encouragement during this period. A very special mention goes to my family;My lovely wife Catherine N. Mpoye, Son Wayne Lekishon ole Saoli, Dad, Joshua Martine Saoli, Mum, Joyce Ene Saoli and my siblings. Thank you so much for the boundless support throughout the years I was engaged in studies. Cate, you came into my life when I needed it most. Receive my heartfelt appreciation for the support, prayers and love. I convey my sincere gratitude for your patience and understanding.

I also convey special gratitude to the staff of Kenyatta University for their technical support throughout this study. A special mention goes to Mary. Thank you for your availability and efficiency in handling my paper work.

\section{References}

i. Agranoff, R. (2014). Local governments in multilevel systems: Emergent public administration challenges. The American Review of Public Administration, 44(4_suppl), 47S-62S.

ii. Agranoff, R., \& McGuire, M. (2001). Big questions in public network management research. Journal of public administration research and theory, 11(3), 295-326.

iii. Ahmed, M.A (2017). The importance of Organizational Structuring and Departmentalization in Workplace. The journal of Middle East and North Africa Sciences, 393),30-38. (P-1SSN 2412-9763) (e-ISNN 2412-8937) www.jomeans.org

iv. Anukwonke, c. c. (2015). The concept of tragedy of the commons: Issues and applications. Retrieved from: https:/ / www.researchgate.net/ publication/ 277708953

v. Baerlein, T., Kasymov, U., \& Zikos, D. (2015). Self-governance and sustainable common pool resource management in Kyrgyzstan. Sustainability, 7(1), 496-521.

vi. Brando, N., Boonen, C., Cogolati, S., Hagen, R., Vanstappen, N., \& Wouters, J. (2019). Governing as commons or as global public goods: two tales of power. International Journal of the Commons, 13(1).

vii. Barrett, K., \& Greene, R. (2000). Grading the cities: A management report card (information technology). Governing, 13, 31-32.

viii. Bedelian, C. (2014). Conservation, tourism and pastoral livelihoods: wildlife conservancies in the Maasai Mara, Kenya. Pp. 1-300. Ph.D. Thesis. University, Town/ State, Country.

ix. Belussi, F., \& Stabber, U. H. (Eds.). (2012). Managing networks of creativity (Vol. 19). Routledge.

x. Bilton, C. (2014). Manageable creativity. In Creativity and cultural policy (pp. 31-46). Routledge.

xi. Bonan, G. (2016). The Communities and the Community. The Implementation of Administrative Reforms in the Fiemme Valley (Trentino, Italy) during the First Half of the 19th Century. International Journal of the Commons, 10(2):589-616, http:// doi.org/ 10.18352/ ijc.741.

xii. Borén, T., \& Young, C. (2013). Getting creative with the 'creative city'? Towards new perspectives on creativity in urban policy. International Journal of Urban and Regional Research, 37(5), 1799-1815.

xiii. Chomba, S., Kariuki, J., Lund, J. F., \& Sinclair, F. (2016). Roots of inequity: How the implementation of REDD+ reinforces past injustices. Land Use Policy, 50, 202-213.

xiv. Curtis, D. R. (2013). Tine De Moor's 'Silent Revolution'. Reconsidering her theoretical framework for explaining the emergence of institutions for the collective management of resources. International Journal of the Commons 7:209-229. http:// dx.doi.org/ 10.18352/ijc.354. work and rewards: Part 1. Compensation \& Business Review, 27-36.

xv. Daft, R. L., \& Marcic, D. (2013). Building management skills: An action-first approach. Cengage Learning.

xvi. Demir, K. A., \& Ozkan, B. E. (2015). Organizational change via social hubs: a computer simulation based analysis. Procedia-Social and Behavioural Sciences, 210, 105-113.

xvii. Dunmore, D. (2013). Has technology become a need? A qualitative study exploring three generational cohorts' perception of technology in regards to Maslow's hierarchy of needs (Doctoral dissertation, Capella University).

xviii. Forsyth, T., \& Johnson, C. (2014). Elinor Ostrom's legacy: governing the commons, and the rational choice controversy. Development and Change, 45(5), 1093-1110.

xix. Fisher, B., Kulindwa, K., Mwanyoka, I., Turner, R. K., \& Burgess, N. D. (2010). Common pool resource management and PES: lessons and constraints for water PES in Tanzania. Ecological Economics, 69(6), 1253-1261.

xx. Fowler, F. C. (2000). Policy studies for educational leaders: An introduction. Upper Saddle River, NJ: Merrill. 
xxi. Gething, P. W., Noor, A. M., Gikandi, P. W., Ogara, E. A., Hay, S. I., Nixon, M. S., ... \& Atkinson, P. M. (2006). Improving imperfect data from health management information systems in Africa using space-time geostatistics. PLoS Medicine, 3(6), e271.

xxii. Hess, C., \& Ostrom, E. (2006). A framework for analysing the microbiological commons. International Social Science Journal, 58(188), 335-349.

xxiii. Howlett, M., \& Newman, J. (2010). Policy analysis and policy work in federal systems: Policy advice and its contribution to evidence-based policy-making in multi-level governance systems. Policy and Society, 29(2), 123136.

xxiv. Homewood, K., Lambin, E.F., Coast, E., Kariuki, A., Kikula, I., Kivelia, J., Said, M., Serneels, S. \& Janssen, M. A. (2013). The Role of Information in Governing the Commons: Experimental Results.

xxv. Johnsson, M., \& Karlsson, H. (2011). Existence of negative innovation-gaps affecting innovation performance in two Swedish SMEs.

xxvi. Kariuki, J., Birner, R., \& Chomba, S. (2018). Exploring institutional factors influencing equity in two payments for ecosystem service schemes. Conservation and Society, 16(3), 320-337.

xxvii. Kariuki, J., \& Birner, R. (2016). Are market-based conservation schemes gender-blind? A qualitative study of three cases from Kenya. Society \& natural resources, 29(4), 432-447.

xxviii. Klijn, E. H., Steijn, B., \& Edelenbos, J. (2010). The impact of network management on outcomes in governance networks. Public administration, 88(4), 1063-1082.

xxix. Klijn, E. H., \& Koppenjan, J. (2012). Governance network theory: past, present and future. Policy \& Politics, 40(4), 587-606.

xxx. Klijn, E. H., \& Koppenjan, J. F. (2006). Institutional design: changing institutional features of networks. Public management review, 8(1), 141-160.

xxxi. Klijn, E. H., \& Koppenjan, J. F. (2000). Public management and policy networks: foundations of a network approach to governance. Public Management an International Journal of Research and Theory, 2(2), 135-158.

xxxii. Kiskis, M. (2012). Understanding the Canadian Innovation System. SOCIALINIAI MOKSLAI, (1), 75.

xxxiii. Koppenjan, J. F. M., \& Klijn, E. H. (2004). Managing uncertainties in networks: a network approach to problem solving and decision making (Vol. 40). London: Routledge.

xxxiv. Laborda Pemán, M. (2017). Beyond Markets and Hierarchies in Pre-Industrial Europe. The Evolution of Institutions for Collective Action in Historical Perspective. Utrecht University: Unpublished PhD thesis.

xxxv. Lamprey, R. H., \& Reid, R. S. (2004). Expansion of human settlement in Kenya's Maasai Mara: what future for pastoralism and wildlife. Journal of Biogeography, 31(6), 997-1032.

xxxvi. Libecap, G. D. (2008). State regulation of open-access, common-pool resources. In Handbook of new institutional economics (pp. 545-572). Springer, Berlin, Heidelberg.

xxxvii. Lipsky, M. (2010). Street-level bureaucracy: Dilemmas of the individual in public service. Russell Sage Foundation.

xxxviii. Lubell, M., \& Fulton, A. (2008). Local Policy Networks and Agricultural Watershed Management. Journal of Public Administration Research and Theory: J-PART, 18(4), 673-696. Retrieved from http:// www.jstor.org/ stable/ 25096389.

xxxix. McGuire, M. (2002). Managing networks: Propositions on what managers do and why they do it. Public administration review, 62(5), 599-609.

xl. Marcel Mithas, S., Ramasubbu, N., \& Sambamurthy, V. (2011). How information management capability influences firm performance. MS quarterly, 35(1), 237.

xli. Masika, M. M., Omondi, G. B., Natembeya, D. S., Mugane, E. M., Bosire, K. O., \& Kibwage, I. O. (2015). Use of mobile learning technology among final year medical students in Kenya. Pan African Medical Journal, 21(1).

xlii. McGuire, M., \& Agranoff, R. (2011). The limitations of public management networks. Public Administration, 89(2), 265-284.

xliii. Mechling, L. C., Gast, D. L., \& Seid, N. H. (2010). Evaluation of a personal digital assistant as a self-prompting device for increasing multi-step task completion by students with moderate intellectual disabilities. Education and Training in Autism and Developmental Disabilities, 422-439.

xliv. Moynihan, D. P., \& Soss, J. (2014). Policy feedback and the politics of administration. Public Administration Review, 74(3), 320-332.

xlv. Mugenda, O. M., \& Mugenda, A. G. (2003). Research Methods: Sample size determination. African Centre for Technology Studies.

xlvi. Mwangi", E. (2016). Socioeconomic change and land use in Africa: the transformation of property rights in Maasailand. Springer.

xlvii. Njogu, J.G. and T. Dietz. (2006). Land use and tenure entitlement. Rights for community-based wildlife and forest Conservation in Taita Taveta, Kenya. IDS Working Paper, number 542. Institute for Development Studies.

xlviii. Ostrom, E. (2012). The challenge of common-pool resources. Environment: Science and Policy for Sustainable Development, 50(4), 8-21.

xlix. Ostrom, E., Gardner, R., Walker, J., Walker, J. M., \& Walker, J. (2012). Rules, games, and common-pool resources. University of Michigan Press.

l. Pemán, M. L., \& De Moor, T. (2013). A tale of two commons. Some preliminary hypotheses on the long-term development of the commons in Western and Eastern Europe, 11th-19th centuries. International Journal of the Commons, 7(1). 
li. Poteete, A. M., M. A. Janssen, and E. Ostrom. (2010). Working Together: Collective Action, the Commons, and Multiple Methods in Practice. Princeton, NJ: Princeton University Press.

lii. Putzel, L., Kelly, A. B., Cerutti, P. O., \& Artati, Y. (2015). Formalization as development in land and natural resource policy. Society \& Natural Resources, 28(5), 453-472.

liii. Rogan, M., \& Greve, H. R. (2015). Resource dependence dynamics: Partner reactions to mergers. Organization Science, 26(1), 239-255.

liv. Rosenbloom, D. H., O'Leary, R., \& Chanin, J. (2017). Public administration and law. Routledge.

lv. Rhodes, R. A. (2016). Policy network analysis. The Oxford handbook of public policy, 423-445.

lvi. Schlager, E., \& Heikkila, T. (2011). Left high and dry? Climate change, common-pool resource theory, and the adaptability of western water compacts. Public Administration Review, 71(3), 461-470.

lvii. Serrano-Álvarez, J. A. (2014). When the enemy is the state: common lands management in northwest Spain (1850-1936). International Journal of the Commons 8:107-133. http:// dx.doi.org/ 10.18352/ijc.389.

lviii. Sidney, M. S. (2017). Policy formulation: design and tools. In Handbook of public policy analysis

lix. (pp.105-114). Routledge.

lx. Van Laerhoven, F., \& Barnes, C. (2014). Communities and commons: the role of community development support in sustaining the commons. Community Development Journal, 49(suppl_1), i118-i132.

lxi. Wanyonyi, E. W. (2012, January). Mobilizing resources for wildlife conservation in Kenya beyond the 21st century. In The George Wright Forum (Vol. 29, No. 1, pp. 118-125). George Wright Society. 